\title{
Transposition
}

Musique et Sciences Sociales

Musique : patrimoine immatériel ?

\section{HeritaMus: A Tool for Collaborative Curation of Tangible and Intangible Heritage}

HeritaMus : un outil de curation collaborative du patrimoine matériel et immatériel

Pedro Félix

\section{OpenEdition}

\section{Journals}

Electronic version

URL: http://journals.openedition.org/transposition/3410

DOI: 10.4000/transposition.3410

ISSN: $2110-6134$

Publisher

CRAL - Centre de recherche sur les arts et le langage

Electronic reference

Pedro Félix, «HeritaMus: A Tool for Collaborative Curation of Tangible and Intangible Heritage »,

Transposition [Online], 8| 2019, Online since 15 September 2019, connection on 17 December 2020.

URL : http://journals.openedition.org/transposition/3410; DOI : https://doi.org/10.4000/transposition. 3410

This text was automatically generated on 17 December 2020 .

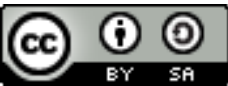

La revue Transposition est mise à disposition selon les termes de la Licence Creative Commons Attribution - Partage dans les Mêmes Conditions 4.0 International. 


\title{
HeritaMus: A Tool for Collaborative Curation of Tangible and Intangible Heritage
}

\author{
HeritaMus : un outil de curation collaborative du patrimoine matériel et \\ immatériel
}

Pedro Félix

1 Once the notions of tangible assets and intangible knowledge become noncontroversial and "heritage" enters a process of generalized recognition, assets and knowledge take different paths. In current heritage practice, "assets" are treated as archival and/or museological items, while "knowledge" is the subject of monographs and scientific papers, or goes untreated and is eventually forgotten. With this separate, differentiated approach, tangible and intangible heritage usually do not intersect.

With over 226 inscribed manifestations in which music plays a role, the ICH list has become the most relevant laboratory for exploring music as intangible heritage in articulation with its tangible assets. The program also establishes a privileged framework for considering the impact of the socio-political processes of "patrimonialization" (when stressing valorisation), "heritization" (when stressing transmission) and "touristification". ${ }^{1}$ HeritaMus is a three-year European project funded by the Joint Program Initiative for Cultural Heritage (JPI-CH), a research consortium of three research groups (Instituto de Etnomusicologia - centro de estudos em música e dança [INET-MD], Univ. Nova de Lisboa; Univ. de Sevilla; Centre de Recherche en Ethnomusicologie, CNRS / Univ. de Nanterre), two associate partners (Museu do Fado; Centro Andaluz de Documentación del Flamenco), and a technical partner (Laboratoire d'Informatique Avancée de Saint-Denis, Univ. Paris 8), aimed at designing a tool (software) for registering both tangible and intangible heritage on a single platform, and thus overcoming the limitations that come with separating them. ${ }^{2}$ Simultaneously, this tool would bypass the usual obstacles to knowledge transfers from academia to the community through implementing this new resource for the management and dissemination of historical documents based on a cooperative 
research model. This was the core aim of the JPI-CH Heritage Plus Program and the focus of the HeritaMus project: to implement a sustainable strategy for protecting and managing cultural heritage; to research the uses and re-uses of different kinds of cultural heritage; and to safeguard tangible cultural heritage (in our current case, historical sound recordings) as fundamental documents of cultural practices (music as ICH).

3 The HeritaMus project took fado and flamenco, their practices, knowledge and assets, as its ethnographic research field, mobilizing both communities of practitioners and stakeholders ${ }^{3}$. Both manifestations are already inscribed on the UNESCO ICH list, but each has a specific contextual implementation process, with different safeguarding plans, reflecting and affecting current national perceptions on heritage. ${ }^{4}$

\section{The project background}

4 In Portugal, over the past 25 years, key research has been conducted on "rural traditions" and on fado (among many other subjects), ranging from the seminal work of Salwa Castelo-Branco ${ }^{6}$ to the work produced at INET-MD, the leading institution in the HeritaMus project. Flamenco, with its strong influence of nationalistic movements, ${ }^{7}$ was subject of studies throughout the $20^{\text {th }}$ century and continues to be so in the $21^{\text {st }}$ century, notably in Spain with the recent work of Cristina Cruces Róldan. ${ }^{8}$

5 From the outset, "heritage" practices have been dominated either by a nexus of "cultural evolution" or by a theory of "romantic nationalism". These two perspectives influenced the design of intervention programs among both communities and stakeholders. Constrained by fears of modernization, innovation and globalization, actors mobilized themselves around a very specific and restrained understanding of "tradition". From folklorists to ethnomusicologists and from collectors to anthropologists, with the support of local politicians, they all determined what should be ranked as "pure", "old", "true", "non-contaminated", "traditional", 9 selectively choosing cultural elements to uphold certain aspects of cultural practices according to their aesthetic and cultural values and their political agendas, determining "authenticity", what is "valuable", and correspondingly establishing the "canon". These actions prioritised the cultural transmission, education and dissemination of those elements established as "pure" and deserving of safeguarding from some "eminent threat". ${ }^{10}$ Researchers thus became "arbiters of cultural genuineness" ${ }^{11}$ and effectively actors manipulated by cultural brokers. ${ }^{12}$ Thanks to the work of researchers such as Hobsbawm, Anderson, Handler, Bohlman, Boissevain, Baumann and Kirshenblatt-Gimblett ${ }^{13}$ and the new field of "critical heritage studies", as well as the impact of the ICH UNESCO program, new debates and perspectives have emerged. This is the context in which HeritaMus is based, seeking to contribute by focusing on such "inauthentic" materials as commercialized recordings, which until recently were considered unworthy of academic attention, heritage recognition and government support.

6 Over the last three decades, awareness of cultural heritage beyond its tangible existence has become a key concern in the field of cultural politics. The concept of ICH, forged by UNESCO, works as a new heritage tag to label "the practices, representations, expressions, knowledge, skills-as well as the instruments, objects, artefacts and cultural spaces associated therewith-that communities, groups and, in some cases, 
individuals recognize as part of their cultural heritage". ${ }^{14}$ Any ICH item has to have a historical trace ("transmitted from generation to generation") and hold relevance to its practitioners ("provides [the communities] with a sense of identity"), but not be a crystallized practice ("constantly recreated"). ${ }^{15}$ The UNESCO ICH program has had significant impact on state cultural politics, cultural tourism, local and transnational economies and the communities of practice, as well as academia. This rising interest has generated a large bibliography, notably including the works of the aforementioned Kirshenblatt-Gimblett, but also Aikawa, Baghli, Kurin, van Zanten and Harrison, and the work of institutions such as ICOMOS and research groups including the Association of Critical Heritage Studies. Indeed, ICH has been warmly received and cherished around the world. In the first decade since the implementation of the ICH convention in 2006, 508 manifestations from 122 countries have joined the UNESCO list. At present, many more proposals have already been prepared, are under preparation or are in the planning phase for submission in the years to come. These processes sometimes affect cultural manifestations because of their tendency to highlight "anti-mainstream", "resistance" or "at risk" aspects. This dominant point of view considers "inauthentic" forms (such as commercialized recordings) unworthy of academic attention, heritage recognition and government support, limiting the understanding of "heritage" to "traditional" practices. Heritage, musical practices and musical industries have seldom been interrelated concepts in research projects.

7 However, like tango or samba, fado and flamenco were first targeted by the commercial strategies of the international phonographic industry in order to boost gramophone sales by building up local catalogues of sound recordings. After the invention of sound recording and reproduction technologies and the advent of the phonographic industry, companies always acted internationally by publishing art music recordings and promoting transnational "stars", but also locally by publishing recordings of local musical genres, repertoires and musicians to feed local gramophone markets (which came to be known as "local catalogues"16). The research process for drafting the fado proposal to the UNESCO ICH list identified the largest historical phonogram collections in Portugal (public and privately owned) with over 12,000 recorded fados surveyed and, now already protected under the ICH safeguarding program, more than 3,000 phonograms (published between 1904 and 1959) that have been digitized and made freely available. ${ }^{17}$ In Andalusia, the Centro Andaluz de Documentación del Flamenco has been conducting a similar study on the historical flamenco discography, with their archive now containing 2,400 $78 \mathrm{rpm}$ shellac recordings, out of a total universe of around 75,000 recordings. In both cases, for the first time, a significant proportion of historical recordings are thus available for study and dissemination. Nowadays, these century-old recordings are considered by the community of practitioners, stakeholders and some researchers as "authentic" representations of "old" traditional musical forms, historically tangible documents of intangible practices and cultural manifestations, ${ }^{18}$ shaping an organic notion of "heritage" in which the industrial modes of production and technical characteristics of the sound carrier are at least somewhat "transparent".

8 However, both communities of practice changed with the development of sound recording, which inevitably impacted musical practices, modifying the characteristic elements of the respective musical genre, while also fostering the professionalization of musicians, as studied by Bithell and Hill ${ }^{19}$ in their work on post-revival musical processes. Professionalization was, in fact, a stock-in-trade, central and determinant 
fact informing the musical practice, the practitioners' lives, and the cultural universes of musical genres from the early $20^{\text {th }}$ century onwards. A number of researchers have studied the use of "traditional" cultural manifestations by phonographic industries in "post-industrial" societies, ${ }^{20}$ and a new scientific interest in historical commercial sound recordings has emerged, ${ }^{21}$ with historical sound recordings of "traditional" practices becoming a regular topic at academic meetings (e.g. the world conferences of the International Council for Traditional Music or the International Association of Sound and Audiovisual Archives). Historical commercial recordings are now central in the study of musical genres, identity configurations, and community shapes and structures. ${ }^{22}$ However, this growing interest has not developed in the same way in museology. While a similar trend can be seen in the display of ICH in general, and musical practices in particular, and some authors have proposed display strategies, ${ }^{23}$ music and its performativity-and the gathering of different human and non-human actors to interact in exhibitions-still remains a very rare subject of reflection. ${ }^{24}$ In fact, not uncommonly do we encounter historical sound recordings exhibited as mere objects, as illustrations, laying still and silenced inside some display case.

For all these reasons, a critical approach to the assessment of the legal instrument (the UNESCO ICH convention) is urgently required, taking into consideration its appropriation by different actors, and coping with new, sometimes unexpected, transnational actors (from phonographic companies and blockbuster exhibitions to cultural tourism and "low cost" airline companies)..$^{25}$ In keeping with its multiple dimensions (as practice and knowledge, but also commercialized goods on technical devices), we need a multi-layered understanding of the universes of musical practices, demanding new theoretical frameworks that intricately interconnect heritage and museum studies, anthropology and ethnomusicology (as the lead academic fields), ethnography and historical documents, identity and memory, practices and knowledge (as fieldwork topics). This furthermore requires the means of tracking different assembled actors, with their own particular politics, i.e. new, versatile, and dynamic tools for tracing and understanding the effects of those phonograms on processes of learning musical practice, the ways in which these actors have shaped change (promoting or preventing it), and whether they work in the same way as a deferred form of "oral transmission". We thus need to consider commercial sound recordings not as static representational objects but rather as non-human actors that "make do" human actors.

\section{The project}

With HeritaMus, by focusing specifically on the relationship between heritage practices (by different types of actors, from musicians to researchers, institutions and companies), sound documents (historical recordings) and current uses and re-uses of community histories (both by the cultural manifestation stakeholders and the community of practitioners), we developed an innovative approach through a cooperative research program between the stakeholders and communities of fado in Portugal and flamenco in Spain, supported by the development of a new management and research tool (software). The project focused on deepening the intricate relationship between intangible heritage (knowledge, memory and identity) and tangible heritage (specifically, historical sound recordings), gathering all kinds of 
actors (human and non-human, intangible and tangible) and tracing their actor networks using new tools for the visualization of complex data. Throughout HeritaMus, we approached the uses of historical commercial recordings-now understood by the communities as historical documents of past practices-in order to understand the genres' memory-shaping and heritage configuration processes.

11 The project focuses on the relationship between phonographic companies, local markets and local "traditional"/"native" repertoires as well as perceptions and usages of phonograms in the respective communities of practice. Taking into consideration the recent interest in heritage, studies on phonography/phonomusicology ${ }^{26}$ and revival processes, in HeritaMus we also critically assessed folklore, revival, heritage theories and the impact of historical sound documents (particularly historical commercial recordings) on cultural communities, musical genres and the community's actual understanding of what constitutes the "traditional repertoire".

In its essence, the project's theoretical framework is designed around Latour's work. According to Latour, modernity systematically refuses to consider the rights of objects, because of its systematic propensity to separate subjects and objects, recognizing agency as an exclusive characteristic of human actors. With HeritaMus, we recognize the full rights, autonomy and agency of any actor, be it human or non-human. Our main focus is to ground research in an intense dialogue between human actors (such as musicians) and non-human actors (such as $78 \mathrm{rpm}$ shellac recordings), while knowing from the outset that both are essential actors in the process of shaping the musical genre, its community, history, musical elements, practices and identity. This framework enables us to perceive all actors as "activists" (entities with a reason to act towards the promotion, dissemination and design of any manifestation) with more or less complex agendas, in association with the prevailing network of constraints (social, historical, political, cultural, identity, economic), with their actions primarily striving to construct an idea of "legitimacy" (connected with notions like "authenticity", "value", "truth", "ancient", "timeless") through performance, narratives and worldviews (of stakeholders, companies, academic institutions, researchers, museums, archives, festivals, cultural tourism promoters, "artists" and so on, with some of themacademic institutions, for example-remaining under-scrutinized). ${ }^{27}$

HeritaMus is an acronym combining "Heritage" and "Music", echoing Latour's "Cogitamus". ${ }^{28}$ Just like "cogitamus", or "we think"-no longer the Cartesian "cogito", or "I think"-HeritaMus highlights the multiple acts of producing heritage carried on by multiple actors when they listen, play, speak, remember, learn, collect, safeguard, give access and research. Conventionally, in academic, museological, archival and heritage circles, the heritage act is assigned to designated specialists. HeritaMus instead focuses on bringing the communities of practice into the process of creating heritage by registering their own narratives. The HeritaMus project does not aim to recover some long-forgotten history or neglected heritage or restore interrupted practices, nor does it aim to re-attribute lost "integrity" or revive the past in present practices. HeritaMus instead seeks to critically study the dynamics among human and non-human actors by following their associations, identifying and studying their reasons, motives, mobilization, cooperation, opposition and conflict, and tracing their fluid networks (mapping all kinds of change: in processes, contexts, histories, identities, values, aesthetics, techniques, actors and musical materials), knowing that the "past" and "heritage" are also non-human actors positioned in that fluid network 
mobilized around cultural manifestations. As such, this project places its focus on the tensions between "tradition" and "living practice", the apparent paradox of safeguarding "traditional"/transmitted knowledge that is constantly changing ("living practice"), something that all ICH project stakeholders recognize as a fundamental and difficult challenge.

\section{The research process}

HeritaMus therefore combines approaches from different areas of study (anthropology and ethnomusicology, museum and heritage studies) and skills (ethnography, computer programming, recorded sound analysis, sound archive management, audio restoration, database design, visual representation of complex data, and museum and display technologies). The tool was successfully developed by a transdisciplinary research team with multi-faceted researchers (social scientists with database programming experience), stakeholders and community practitioners, whose knowledge was integrated and valued, alongside associated partners serving as mediators and beta-testers.

15 As large amounts of historical sound documents recently became available to both communities, we started out with the datasets on phonograms. Fado and flamenco were the chosen cultural practices for this research as they both hold a history of commercial sound recording-some still remaining unknown to the present community of practice-and similar transmission modalities based on organic, lifelong processes of acculturation and apprenticeship that mobilize complex networks of actors, from teachers to recordings, from recording publishers to museums, from academia to private archives and collections. Taking these collections as raw historical data, the project was structured into three phases:

16 1) Preliminary inventory of materials (for eight months, mobilizing the entire HeritaMus consortium and more than a dozen members from both the fado and flamenco communities). In this phase, we built up an experimental laboratory, centred around cooperative interactions between researchers and stakeholders for the analysis of data, promoting fluid assemblages of improbable and unexpected objects, places, people, ideas, values, techniques, gathered to organize the "community's knowledge and things", taking special care with regard to the effective difficulties of representing ICH. The laboratory sessions were based on open discussions about display strategies, usability and concept validation in order to establish a knowledge structure able to depict tangible assets and intangible knowledge, human and non-human actors, in an articulated manner and on the same plane, without sacrificing fluidity-the unexpected and ever-changing alliances and oppositions. The researchers proposed new forms of representation (through graph design) in order to highlight non-human agency, the tangibility of intangible heritage, the materiality of knowledge for a new post-social political world in which agents are fluid, unexpected, changing alliances (sometimes blocking, on other occasions cooperating).

17 2) Design of the digital tool (for nineteen months, split into two phases, involving the Portuguese and French partners). The digital tool is the technical core of the HeritaMus project. Based on the historical and ethnographic information gathered, the tool allows for the registration of associations between items, thereby tracing a network of actors. The graph database was programmed according to the needs of anthropological and 
ethnomusicological research, while the interface is adapted to the community of stakeholders and practitioners. Thus, theoretical issues informed the structure, and the interface was designed to offer a user-friendly digital environment. The tool (software) is a complex, multi-level, graph database for the management of fundamental historic and ethnographic raw data able to support future safeguarding programs for both tangible and intangible heritage, in addition to recording any actions taken over time (specifically technical actions, the input of new data as well as tracing more complex processes of cultural practices change). The graphs are applied to data input, retrieval and visualization. They enable the systematic analysis of complex cultural manifestations of different kinds of materials usually dispersed across unrelated, hierarchical and atomistic databases. With HeritaMus, users can easily convey complex networks of human and non-human actors, promoting new interpretations and knowledge based on unexpected relationships.

18 3) Field research (for twenty-three months, split into two phases concurrent with the development of the digital tool, involving the Portuguese and Spanish consortium members, the two associate partners and hundreds of members of both communities, particularly the fado community). The ethnographic study focused on the way in which communities of practitioners organize their worldview and their usage of historical sound recordings, based on free association audio-elicitation sessions conducted with community "activists" (chosen on the basis of previous ethnographic knowledge of the community, taking into account their knowledge of the manifestation in question and their recognition by the respective community). Presenting the selected recordings to the practitioners, the researchers proceeded to record the comments and reactions to those sounds, attempting to understand the ways in which stakeholders classify and perceive their community's heritage, and how these elements affect their present actions (in terms of aesthetically and technically assessing their peers and their performance). Special attention was paid to participants' perceptions, aesthetic values and reflections upon history in a process of intense contextualization, decontextualization, and recontextualization (from "tradition" to "heritage", from "knowers" to "doers" and to "marketers"). In a second and longer period of fieldwork lasting twelve months, a prototype of the tool was tested in order to achieve the final version of the software (released in April 2018).

\section{The tool (software)}

The software is an HTML-based tool for multiple users to register items they consider relevant for the representation of their universe of practice. Each inputted item is a node defined by the relationships it establishes with other nodes. We may represent the most basic input as demonstrated in fig. 1 where item (1) is defined by its relationship-> with item (2). This relationship allows us to consider that node (2) is also defined by its -relationship-> with item (1). As an example, node (1) might be Óscar Cardoso (a guitar maker) and node (2) the Portuguese Guitar, both associated by the relationship type -"makes"->. The Portuguese guitar is defined by those who make it, just as the maker is defined by the instrument he makes. 


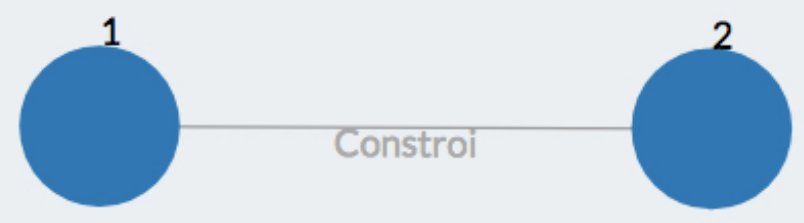

\section{1: Conceptual graph.}

Starting from this basic step, multiple users, through their inputted information, then produce personal graphs that are articulated in more complex graphs, such as the "Fado Macau" example (fig. 2) below.

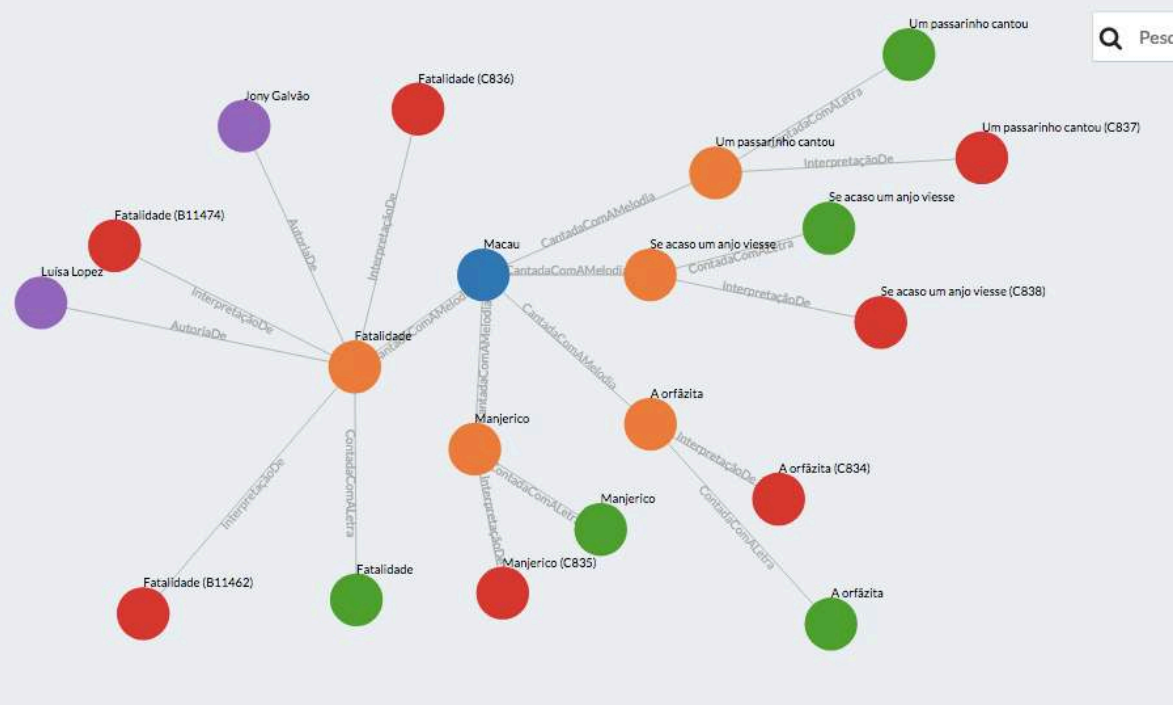

III. 2: Graph of "Fado Macau" with 2 degrees of separation.

21 in which the melody "Fado Macau" (represented in blue) is defined by its relationships with songs (in orange), lyrics (in green), sound recordings (in red) and authors (in purple). Whenever available (for legal reasons), the sound recording can also be played. The "person" node type usually has a brief biographical note associated with it. As more data are inputted and uploaded, the graphs densify, requiring powerful queries and filters (fig. 3). 


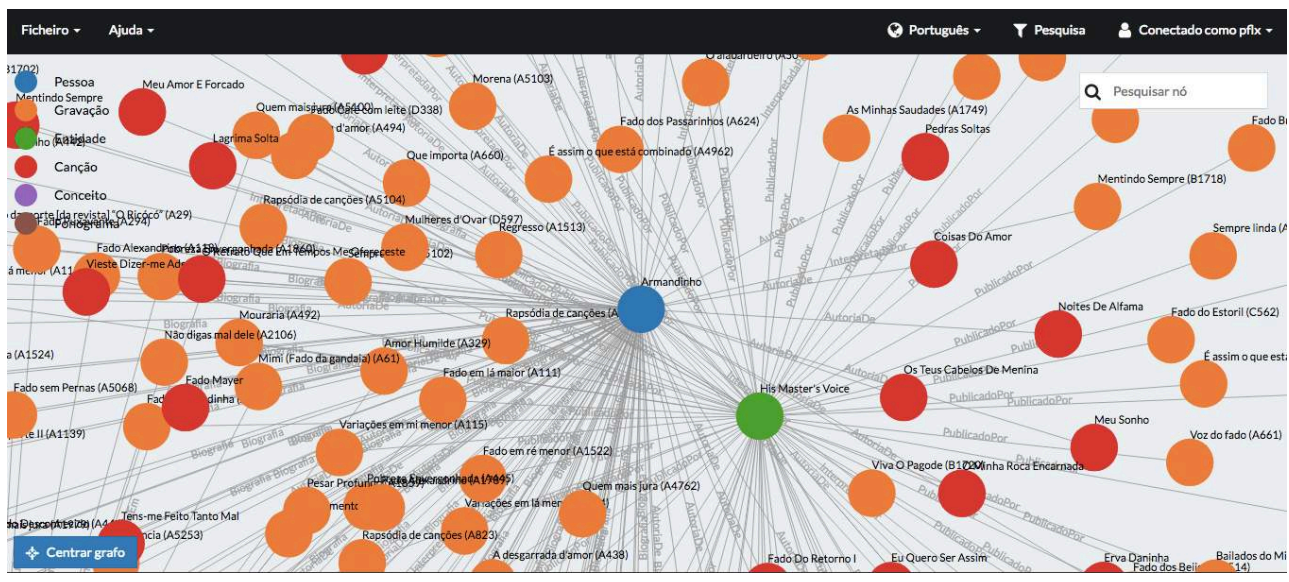

III. 3: Graph of Armandinho with 3 degrees of separation. With HeritaMus, communities are able to register, manage and curate, on their own terms, their knowledge and assets in complex assemblages, gathering multivocal narratives that overcome a world of factual objects separated from human concerns, desires and conflicts. Through HeritaMus and the multi-user contributions to constitute a "general graph", we move from "perspectivalism" to "pespectivism" (a movement conceptualized by Viveiros de Castro); $; 0$ we move from non-intersecting multiple perspectives on heritage to entangled multiple perspectives, co-produced by each other. Invited to record their universes in their own terms, communities shape their personal mind maps of their practices and, simultaneously, produce the "collective", participating in the construction of a community-of-practice map and thereby democratizing museological, archival and curatorial acts. In one way, by following (registering and retrieving) the associations, communities shape themselves on their own terms and for their own purposes, eventually stating their reasons. The knowledge of fado tunes stems from having access to multiple performances and sound recordings. The characteristics of traditional tunes are shaped by the multiple instances of them, from live performances to sound recordings made by multiple performers, recorded in different historical moments and published by different companies.

With this tool we hope to match community needs, interests and expectations. We have reason to believe that, in the near future, the tool will generate new insights for ongoing national and international projects, such as Europeana, Rossio, the Museu do Fado Digital Sound Archive, helping introduce new perspectives, providing a new technical resource for museums and heritage management focused on the need for urgent adaptation to a new and fluid reality-able to accommodate new materials and 
be inclusive (as it relies on stakeholders and community participation), running counter to linear narratives and, above all, being community oriented.

\section{The results}

Apart from new ethnographic and historical data ${ }^{31}$ and the tool itself, I would like to highlight some ideas that emerged from the first operational months of HeritaMus.

HeritaMus has been used by the fado community (where testing was carried out) as a resource to identify persons, entities, tunes and recordings of "traditional fados"; in other words, users are retrieving data to a greater extent than they are inputting new information. The database mainly serves for the identification of authorship and historically less recorded repertoire with the intention of drawing upon the tunes found. Some singers that were then pre-producing their new records asked us to search out long-forgotten fados while others requested historical "traditional" fados, musically similar to more recent and better-known ones, a type of search that is difficult to perform. We envision solutions pointing to a Machine Learning/Artificial Intelligence algorithm-based process fed by ethnographic and historical data to be further collected among the community.

We also learned that, among this community, historical tune nomenclatures are essentially functional, working as melodic references and not as prescribed musical works. A traditional fado is a "set" of minimal musical elements, sufficient for any musician to accompany a singer, both of whom are expected to "create" their own "style" upon the tune of reference. ${ }^{32}$ For this reason, a sound recording of a traditional fado usually adopts the title of the lyric but, for the community, the reference name would be that of the tune. Herein lies another major contribution of HeritaMus. For a conventional archive, the sound recording would be catalogued by the title stated on the phonogram label and not by the tune upon which it was created. Therefore, the sound recordings "Escada sem Corrimão" by Camané and "Deste-me tudo o que tinhas" by Aldina Duarte would not be associated, even though, for the fado community, they both draw on the same "traditional" tune "Fado da Meia-Noite" (composed by Filipe Pinto). Consequently, this type of association would tend to be forgotten over time. On another note, since a fado performer is supposed to create an original melodic development based on the established, known and shared elements of the "traditional" tune, it is also impossible to deploy automatic "music recognition algorithms", at least according to their current designs and capabilities. However, there is now a project under development by some HeritaMus consortium members to address this issue.

Because the community is strongly practice-oriented (like many, if not all, nonacademic musical universes), the conceptualization of the users' practices reflects the predominance of "doing" and "making". Some authors have written about this. ${ }^{33}$ Hence, memory and history-the cornerstone of the community itself-are based on the knowledge of "traditional" tunes, mostly learned from historical sound recordings. For musical communities, after 118 years of sound recording, phonograms play a central role in their daily practices. They are essential non-human actors in the fado community. At HeritaMus, we took the opportunity provided by the recent availability of large amounts of historical recordings, most of them accessible for the first time, to follow the impact that these resources had on the fado community, a community structured according to a narrative of "tradition", "historicity" and "heritage". 

centric". However, there are practical reasons for this. In HeritaMus, other non-human actors may currently be under-represented. For now, we are continuing to work with the large datasets that were available and a certain amount of data inputted by users. However, we remain confident that after their initial contact with the software, users will input other types of actors (human and non-human). Technically, there are no limitations to inputting any kind of human or non-human actor, and we do encourage users to input any lacking typologies. This creates the challenge of finding ways to overcome reification and conveying the idea that anything (and everything) can be an actor/node. Nevertheless, the community already manipulates the actor-network (ANT) toolbox, even if not in a conceptualized fashion. While it is true that the conceptual apparatus established by the ANT is not endogenous to this community (nor is it among any community of practice), it does in fact appropriately reproduce the organization of the community's knowledge. Naturally, the theoretical leap of turning assets and knowledge into nodes associated by relationships is a difficult process that benefits from the assistance of "facilitators".

As expected, there was some resistance to adopting HeritaMus. For the community of practice, there are difficulties in reconfiguring their knowledge and assets into an abstract representation of elements in an associative movement, translating meanings and ideas into nodes associated by relationships. Nevertheless, this was a lower level of resistance than that experienced by the conventional databases otherwise currently available. However, we also encountered some resistance among archivists for whom the option of a local ontology, to the detriment of typified ontologies (such as OWL2), raises doubts concerning content validation and fears of data dispersion and irretrievability.

31 The HeritaMus project seeks precisely to provide a user-friendly tool for collecting and registering unexpected and controversial associations of knowledge and assets. By giving practitioners the opportunity to register and represent ideas and assets on their own terms, it contradicts the dominant modernist system of classification and typologization operated by "the archive", "the museum", and "academia" in their search for a universal representation, an exclusively theoretically abstract reasoning that is correspondingly divorced from the practitioners. We do not proceed as translators of one knowledge system (community narratives) into another (curated knowledge); instead we seek to record the community's own translations (through associations between actors). HeritaMus positions itself against the determinism of conceptual and technically established categories, opening up curatorship to community voices (their interpretation and agency, their "vernacular theories", their "local knowledge", etcetera), "decolonizing the database", ${ }^{34}$ allowing controversies and uncertainties where once there was an artificially shaped "definitive" definition. ${ }^{35}$ It argues that "things" should not be defined exclusively by canonical and disciplinedbased narratives ${ }^{36}$ and authoritative epistemologies. ${ }^{37}$ With HeritaMus, knowledge is registered by its holders, the users of the software, who simply create nodes and trace connections, allowing established narratives and unconventional associations to coexist on the same plane.$^{38}$ By favouring local topologies, it manages to reduce the resistance of the community of practice. From this perspective, adopting local/ community categories in order to reduce the impacts and possible constraints on users is the most basic strategy. Furthermore, as the number of mobilized users grows, the 
clearer their power relations will be, thereby ensuring the symmetry of representations.

We also faced technical limitations on the visualization of larger datasets, representing and depicting controversies, as well as the ultimate goal of setting up a "parliament of things". These issues will be subject to further work and the development of new software technologies. When a node is densely associated with other nodes, the graph becomes very difficult to read. Whenever a node in the general database has more than 300 relationships, the visualization is automatically limited to that number (while displaying a notice that only 300 relationships are being visualized). In order to solve this issue, the team is now working on more powerful and effective queries, based on "natural language" to refine the displayed data.

Any solution based on limiting data input is simply unacceptable. On the contrary, in order to work, HeritaMus needs multiple data sources, multiple actors, because as data becomes denser and the community network becomes clearer, alternative narratives also become noticeable. Based on the data collected, we quickly grasped the weight of "master narratives" echoing the "economy of prestige and reputation" prevailing in the community, which recognizes specific actors and arguments as better consolidated than others, even when practices and shared memories do not support those arguments. This is already noticeable with regard to authorships (of tunes and performative styles) and their recreation across time. Museums, archives and research, by instituting pseudo-neutral systems of classification and documentation, ${ }^{39}$ have been promoting these "master narratives", favouring single over multiple perspectives. "The museum", "the archive", "the academic" and heritage technicians work as prestigious officers of curatorship. And, correspondingly, discourses and agents tend to erase controversies in ways that shape identity- and memory-building processes. We fairly commonly hear: "If he [a reputed actor] says so, who am I to disagree? But [...]". With HeritaMus, we therefore strive for disorder, chaos, flexibility, polyphony, locality, reinforcing accessibility and openness to the heritage narratives..$^{40}$ More than an alternative software tool, we perceive HeritaMus as an ethical imperative. We, researchers, should not "speak on behalf of", but rather "give voice to". ${ }^{41}$ It is time to give back the voices of objects and persons usually excluded from the curation process. ${ }^{42}$ We need assemblages! ${ }^{43}$

Controversies are one of the main victims of the pseudo-neutral logic previously mentioned. They do not exist at institutional repositories of information. Some "famous" controversies (including authorship disputes) have been documented, but as time passes, they are becoming increasingly rare among practitioners. Instead, with HeritaMus, controversy can currently be identified on a generated graph, although we still have to develop our visualization of it in order to be able to easily trace the actors mobilized, their factions and the parties that sustain arguments. One of the most common controversies relates to notions of authenticity and to the aesthetic limits of practice. The flamenco community is particularly sensitive to this kind of controversy. Indeed, we did encounter a strong tendency by the flamenco community to argue for an "authentication" of repertoire and practices, organizing the items based on "true"/"genuine" and "falsified"/"fake" cultural items. These personal objectives in turn generated some tensions among the flamenco stakeholders when confronted with the argument that any validations of "authenticity" are, in themselves, further narratives to be documented, argued and illustrated. 
As controversies remain, it is of the utmost importance that, through HeritaMus, we are able to contribute to the constitution of a "parliament of things". For now, there are certain technical limitations to the software (for the representation of parties) and data (datasets with far too many gaps, particularly for tracing changes across time). Through a free association strategy, we were able to understand how community members organize their knowledge about their practices, history and identity, drawing up a shared cognitive map of the community network on their own terms, but, for the meantime, the technical resources for depicting such a "parliament" are limited. For now, HeritaMus represents a sort of "contact zone", ${ }^{44}$ a space (even if virtual) where multiple actors are drawn together around tangible assets and intangible knowledge, mediating between collections and ideas, people and things, knowledge and practice, for the production of assemblages. HeritaMus gathers knowledge and generates questions, highlights controversies and draws attention to unexplored domains. We have managed to develop a tool that transfers knowledge creation to the community itself, while assuming the risk of recording the community's politics ("versions"). We take into consideration all objects, all typologies, all knowledge, all narratives and arguments, in order to multiply voices and actors in a heritage field rendered a dynamic domain. More than layering "multiple experiences", "interpretations", "views" and "authorities" from multiple actors in order to shape a "universe" of practice, we argue for a "multiverse" mobilized around a topic.

In spite of these problems, HeritaMus provides a new resource and has made new data on sound heritage available, and moreover shed new light on them. We strongly believe that this key outcome of the project will be applied by other communities (of practice, but also technical communities such as museologists, anthropologists, sound archivists) as the tool bridges the gap between stakeholders and academia through an innovative approach to cooperative research, inviting and requesting stakeholders and practitioners to actively participate in the project. Currently, HeritaMus is in use across the fado community. With the revised version of the software, we expect to implement its usage in the flamenco community. Other institutions, some nationwide and others concerned with different topics (such as political documents), are to test its applicability for their representation needs.

Hence, HeritaMus articulates tangible and intangible heritage,${ }^{45}$ considering any actor, registering any association, bringing multiplicity, uncertainty and controversies into the technical act of recording, archiving and musealizing. To achieve this, we brought practitioners and stakeholders into the curation process. We challenged assumed notions and long established "ways of doing" among heritage professionals (researchers, archivists, museologists). Put simply, HeritaMus has enabled the democratization of curatorial acts, cultivating more open and participatory practices, empowering the communities of practice. Through greater participation in curation, we expect better and more useful multiverse representations of community/ communities, enabling the registration of alternative narratives (other than established "master narratives"), providing tools for their own representation and bringing power relations to the fore. With all this, we hope to have played a part in bringing democracy to museums, archives and academia. 


\section{BIBLIOGRAPHY}

ANDERSON Benedict, Imagined Communities. Reflections on the Origin and Spread of Nationalism, London, Verso, 1983.

BAUMANN Max Peter, "Folk Music Revival: Concepts Between Regression and Emancipation”, The World of Music, vol. 38, no. 3, 1996, p. 71-86.

BAYLEY Amanda (ed.), Recorded Music: Performance, Culture and Technology, Cambridge, Cambridge University Press, 2010

BIGENHO Michelle, Sounding Indigenous: Authenticity in Bolivian Music Performance, New York, Palgrave Macmillan, 2002.

BITHELL Caroline, HILL Junipper (eds.), The Oxford Handbook of Music Revival, Oxford / New York, Oxford University Press, 2014.

BOHLMAN Philip V., The Study of Folk Music in the Modern World, Bloomington, Indiana University Press, 1988.

BoISSEVAIN Jeremy (ed.), Revitalizing European Rituals, London / New York, Routledge, 1993. BORTOLOTTO Chiara (dir.), Le patrimoine culturel immatériel : enjeux d'une nouvelle catégorie, Paris, MSH, 2011.

BRADY Erica, A Spiral Way: How the Phonograph Changed Ethnography, Jackson, University Press of Mississippi, 1999.

BRASSEAUX Ryan A., Cajun Breakdown: The Emergence of an American-made Music, Oxford, Oxford University Press, 2009.

BRIGGS Charles L., "The Politics of Discursive Authority in Research on the 'Invention of Tradition”", Cultural Anthropology, vol. 11, no. 4, 1996, p. 435-469 (quote p. 460).

CAMERON Fiona, “Object-Oriented Democracies: Conceptualising Museum Collections in Networks”, Museum Management and Curatorship, vol. 23, no. 3, 2008, p. 229-243.

CANDLIN Fiona, Micromuseology, London, Bloomsbury Academic, 2015.

CASTelo-BRAnco Salwa (ed.), Enciclopédia da Música em Portugal no Século XX, Lisboa, Círculo de Leitores / Temas e Debates, 2010.

CASTELO-BRANCO Salwa, "Etnomusicologia”, CASTELO-BRANCo Salwa (ed.), Enciclopédia da Música em Portugal no Século XX, Lisboa, Círculo de Leitores / Temas e Debates, 2010, p. 419-432.

CASTElo-branco Salwa, "The Dialogue Between Voices and Guitars in Fado Performance Practice", BRITO Joaquim Pais de (ed.), Fado: Voices and Shadows, Lisbon, Museum of Ethnology, 1994 ,

p. $125-140$.

CASTELO-BRANCo Salwa, FREITAS BRANCo Jorge (eds.), Vozes do povo: a folclorização em Portugal, Lisboa, Celta Editora, 2003.

CASTELO-BRANCO Salwa, TOSCANO Manuela, “'In Search of a Lost World': An Overview of Research and Documentation on the Traditional Music of Portugal", Yearbook for Traditional Music, vol. 20, 1988, p. 158-192.

CHILD Francis J. (ed.), English and Scottish Ballads, London, Sampson Low, 1861. 
CHRISTIE Michael, VERRAN Helen, "Postcolonial Databasing? Subverting Old Appropriations, Developing New Associations", LEACH James, wILSON Lee (eds.), Subversion, Conversion, Development: Cross-Cultural Knowledge Exchange and the Politics of Design, Cambridge, MIT Press, 2014, p. 57-78. CIARCIA Gaetano, La perte durable : étude sur la notion de "patrimoine immatériel", Paris, LAHIC / Mission à l'ethnologie, 2006.

CLARKE Eric, COOK Nicholas (eds.), Empirical Musicology: Aims, Methods, Prospects, Oxford, Oxford University Press, 2004.

CLIFFORD James, MARCUS George E. (eds.), Writing Culture. The Poetics and Politics of Ethnography, Berkley, University of California Press, 1986.

сооK Nicholas, Beyond the Score. Music as Performance, Oxford, Oxford University Press, 2013. соок Nicholas, ClARKE Eric, et al. (eds.), The Cambridge Companion to Recorded Music, Cambridge, Cambridge University Press, 2009.

COоK Nicholas, PETTENGILl Richard (eds.), Music as Performance: New Perspectives Across the Disciplines, Ann Arbor, University of Illinois Press, forthcoming.

COTTRELl Stephen, “The Rise and Rise of Phonomusicology”, BAYLEY Amanda (ed.), Recorded Music. Performance, Culture and Technology, Cambridge, Cambridge University Press, 2010, p. 15-36.

CRUCES RÓLDAN Cristina (ed.), Historia del Flamenco, Sevilla, Ediciones Tartessos, 2002.

CRUCES RóLDAN Cristina, Antropología y Flamenco (II), Sevilla, Signatura Ediciones, 2003.

CRUCES RÓLDAN Cristina, El Flamenco como Patrimonio: Anotaciones a la Declaración de los Registros Sonoros de la Niña de los Peines como Bien de Interés Cultural, Sevilla, Ayuntamiento de Sevilla, 2001. CRUCES RÓLDAN Cristina, El Flamenco como Patrimonio: Anotaciones a la Declaración de los Registros Sonoros de la Niña de los Peines como Bien de Interés Cultural, 2001

EARLMAN Veit, Music, Modernity, and the Global Imagination: South Africa and the West, New York, Oxford University Press, 1999.

FEINTUCH Burt, "Revivals on the Edge: Northumberland and Cape Breton - a Keynote", Yearbook for Traditional Music, vol. 38, 2006, p. 1-17.

FÉLIX Pedro, "Ai se Ele Cai": Uma Etnografia da Prática do Grupo Xutos \& Pontapés [PhD thesis], Lisboa, Departamento de Antropologia, FCSH, Universidade Nova de Lisboa, 2013.

FÉLIx Pedro, “Ao Fado Muito se Deve a Implantação da República”, Fado 1910, Lisboa, Museu do Fado, 2010, p. 131-146.

FÉLIX Pedro, Inventário do Património Fonográfico Português: Fado, Lisboa, Museu do Fado, forthcoming.

FÉLIX Pedro, Óscar Cardoso: Guitarreiro, Lisboa, Museu do Fado, 2011.

FILENE Benjamin, Romancing the Folk: Public Memory and American Roots Music, Chapel Hill, University of North Carolina Press, 2000.

GAGLiARdi Pasquale, LATOUR Bruno, MEMElSDorfF Pedro (eds.), Coping with the Past. Creative Perspectives on Conservation and Restoration, Firenze, Leo S. Olschki, 2010.

GEISMAR Haidy, Museum Objects. Lessons for the Digital Age, London, UCL Press, 2018, p. 76.

HANDLER Richard, Nationalism and the Politics of Culture in Quebec, Madison, The University of Wisconsin Press, 1988. 
HARRISON Rodney, BYRNE Sarah, CLARKE Anne (eds.), Reassembling the Collection: Ethnographic Museums and Indigenous Agency, Santa Fé, School for Advanced Research Press, 2013.

HARRISON Rodney, et al. (eds.), Reassembling the Collection: Ethnographic Museums and Indigenous Agency.

HARRISON Rodney, Heritage: Critical Approaches, London, Routledge, 2013.

HILL Juniper, "The Influence of Conservatory Folk Music Programs: the Sibelius Academy in Comparative Context”, Ethnomusicology Forum, vol. 18, n² 2, 2009, p. 205-239.

HOBSBAWM Eric, “Introduction: Inventing Traditions", HOBSBAWM Eric, RANGER Terence (eds.), The Invention of Tradition, Cambridge, Cambridge University Press, 1983, p. 1-14.

JANES Robert R., Museums and the Paradox of Change: A Case Study in Urgent Adaptation, London, Routledge, 2013 [1995].

KEEGAN-PHIPPS Simon, "Déjà vu? Folk Music, Education, and Institutionalization in Contemporary England", Yearbook for Traditional Music, vol. 39, 2007, p. 84-107.

KIRSHENBLATT-GIMBLETT Barbara, "Intangible Heritage as Metacultural Production", Museum International, vol. 56, no. 1-2, 2004, p. 52-65.

KIRSHENBLATT-GIMBLETT Barbara, Destination Culture: Tourism, Museums, and Heritage, Berkeley, University of California Press, 1998.

LATOUR Bruno, "When Things Strike Back: a Possible Contribution of 'Science Studies' to the Social Sciences", British Journal of Sociology, vol. 51, no. 1, 2000, p. 116.

LATOUR Bruno, Cogitamus :six lettres sur les humanités scientifiques, Paris, La Découverte, 2010.

LATOUR Bruno, HERMANT Emilie, Paris Ville Invisible, Paris, Les Empêcheurs de penser en rond \& Le Seuil, 2009 [1998].

LATOUR Bruno, Nous n'avons jamais été modernes : essai d'anthropologie symétrique, Paris, La

Découverte, 1997.

LATOUR Bruno, WEIBEL Peter (eds.), Iconoclash. Beyond the Image Wars in Science, Religion and Art, Cambridge, MIT Press, 2002.

LATOUR Bruno, WeIBEL Peter (eds.), Making Things Public. Atmospheres of Democracy, Cambridge, MIT Press, 2005.

LAW John, After Method: Mess in Social Science Research, London, Routledge, 2004.

LIVINGSTON Tamara E., "Music Revivals: Towards a General Theory”, Ethnomusicology, vol. 43, no. 1, 1999, p. 66-85.

LOMAX Alan, Folk Song Style and Culture, Washington, American Association for the Advancement of Science, 1968.

LONETREE Amy, Decolonizing Museums: Representing Native America in National and Tribal Museums, Chapel Hill, UNC Press Books, 2012.

MACDONALD Sharon, Memorylands. Heritage and Identity in Europe Today, London, Routledge, 2013.

MACHIN-AUTENRIETH Matthew, "Flamenco for Andalusia, Flamenco for Humanity: Regionalisation and Intangible Cultural Heritage in Spain", ROss Sarah, swEERS Britta (eds.), Cultural Mapping and Musical Diversity, Sheffield, Equinox Studies in Ethnomusicology, forthcoming. 
MACHIN-AUTENRIETH Matthew, Flamenco, Regionalism and Musical Heritage in Southern Spain, London, Routledge, 2017.

MACLEOD Suzanne, HANKS Laura H., HALE Jonathan (eds.), Museum Making. Narratives, Architectures, Exhibitions, London, Routledge, 2012.

MANUEL Peter, "Music Cultures of Mechanical Reproduction”, BoHLMAN Philip V. (ed.) The Cambridge History of World Music, Cambridge, Cambridge University Press, 2013, p. 55-74. MARSTINE Janet, Critical Practice. Artists, Museums Ethics, London, Routledge, 2017.

MITHLo Nancy Marie, “Red Man's Burden: The Politics of Inclusion in Museum Settings”, American Indian Quarterly, vol. 28, no. 3-4, 2004, p. 743-763.

NERY Rui V., A History of Portuguese Fado, Lisboa, INCM, 2012.

PRATT Marie Louise, “Arts of the Contact Zone”, Profession, 1991, p. 33-40.

RICKARD Jolene, "Absorbing or Obscuring the Absence of a Critical Space in the Americas for Indigeneity: The Smithsonian's National Museum of the American Indian", Res: Anthropology and Aesthetics, no. 52, 2007, p. 85-92.

RONSTRÖM Owe, "Revival Reconsidered", The World of Music, vol. 38, no. 3, 1996, p. 5-20.

ROSENBERG Neil (ed.), Transforming Traditions: Folk Music Revivals Examined, Urbana, University of Illinois Press, 1993.

SCULLY Michael F., The Never-Ending Revival: Rouder Records and the Folk Alliance, Urbana, University of Illinois Press, 2008.

SHELEMAY Kay Kaufman, "Recording Technology, the Record Industry, and Ethnomusicological Scholarship", NETTL Bruno, BOHLMAN Philip V. (eds.), Comparative Musicology and Anthropology of Music: Essays on the History of Ethnomusicology, Chicago, The University of Chicago Press, 1991, p. 277-292.

SILVERMAN Raymond, Museums as Process. Translating Local and Global Knowledges, London, Routledge, 2014.

SMALL Christopher, Musicking: the Meanings of Performing and Listening, Middletown, Wesleyan University Press, 1998.

SMITH Laurajane, AKAGAWA Natsuko (eds.), Intangible Heritage, London, Routledge, 2009.

TAYLOR Timothy D., Beyond Exoticism: Western Music and the World, Durham, Duke University Press, 2007.

TAYLOR Timothy D., Global Pop: World Music, World Markets, London, Routledge, 1997.

TSCHMUск Peter, Creativity and Innovation in the Music Industry, Heidelberg, Springer, 2012.

VASCONCELLOS Jorge Leite, Etnografia Portuguesa, Lisboa, INCM, 1994 [1933].

VIVEIROS DE CASTRo Eduardo, "Cosmological Deixis and Amerindian Perspectivism", The Journal of the Royal Anthropological Institute, vol. 4, no. 3, 1998, p. 469-488.

WASHABAUGH William, Flamenco Music and National Identity in Spain, Farnham, Ashgate, 2012.

WEIBEL Peter, LATOUR Bruno, "Experimenting with Representation: Iconoclash and Making Things Public", MACDONALD Sharon, BASU Paul (eds.), Exhibition Experiments, Malden, Blackwell Publishing ltd., 2007, p. 94-108. 
WEISENTHAUNET Hans, LINDBERG Ulf, “Authenticity Revisited: The Rock Critic and the Changing Real”, Popular Music and Society, vol. 33, no. 4, 2010, p. 465-485.

\section{NOTES}

1. To trace some of the debates, see relevant works by воRтоLоTто Chiara (dir.), Le patrimoine culturel immatériel: enjeux d'une nouvelle catégorie, Paris, MSH, 2011; HARRISON Rodney, Heritage: Critical Approaches, London, Routledge, 2013; KIRSHENBLATT-GIMBLETT Barbara, Destination Culture: Tourism, Museums, and Heritage, Berkeley, University of California Press, 1998; KIRSHENBLATTGIMBLETT Barbara, "Intangible Heritage as Metacultural Production”, Museum International, vol. 56, no. 1-2, 2004, p. 52-65; SMITH Laurajane, AKAGAWA Natsuko (eds.), Intangible Heritage, London, Routledge, 2009.

2. For more information and access to the Heritamus software, see heritamus.fcsh.unl.pt (accessed April 16, 2019).

3. The concept of stakeholder is used in the sense of a person or group of persons who have public responsibilities and / or represents interests of a community or parts of the community. At Heritamus some stakeholders were involved and mobilized in the design and implementation of the project.

4. In the case of the fado community, the work carried out by Museu do Fado (opened in 1998) after 2005, in preparing the proposal for UNESCO, and since 2011, once enlisted, on the safeguarding program (particularly focusing on the archival treatment of historical sound recordings, among other tasks), has led to an unprecedented amount of heritage work, always in keeping with the standards of best practice: setting up a digital sound archive, carrying out historic and ethnographic research, with dozens of books published and exhibitions held, organizing hundreds of conferences and thousands of community events, and, above all, bringing together a mobilized community of practice with multiple stakeholders.

5. CASTElo-Branco Salwa, "The Dialogue Between Voices and Guitars in Fado Performance Practice", BRITO Joaquim Pais de (ed.), Fado: Voices and Shadows, Lisbon, Museum of Ethnology, 1994, p. 125-140; CASTELO-BRANCo Salwa (ed.), Enciclopédia da Música em Portugal no Século XX, Lisboa, Círculo de Leitores / Temas e Debates, 2010; NERY Rui V., A History of Portuguese Fado, Lisboa, INCM, 2012; FÉLIX Pedro, “Ao Fado Muito se Deve a Implantação da República”, Fado 1910, Lisboa, Museu do Fado, 2010, p. 131-146; FÉLIx Pedro, Óscar Cardoso: Guitarreiro, Lisboa, Museu do Fado, 2011; and the work carried out since 2005 by both Museu do Fado and INET-MD for the elaboration of the ICH proposal to UNESCO.

6. castelo-Branco Salwa, "Etnomusicologia”, castelo-BRAnCo Salwa (ed.), Enciclopédia da Música em Portugal no Século XX, Lisboa, Círculo de Leitores / Temas e Debates, 2010, p. 419-432; CASTELoBRANCo Salwa, FREITAS BRANCo Jorge (eds.), Vozes do povo: a folclorização em Portugal, Lisboa, Celta Editora, 2003; CASTELO-BRANCO Salwa, TOSCANO Manuela, “'In Search of a Lost World': An Overview of Research and Documentation on the Traditional Music of Portugal", Yearbook for Traditional Music, vol. 20, 1988, p. 158-192.

7. WASHABAUGH William, Flamenco Music and National Identity in Spain, Farnham, Ashgate, 2012; MACHIN-AUTENRIETH Matthew, Flamenco, Regionalism and Musical Heritage in Southern Spain, London, Routledge, 2017; MACHIN-AUTENRIETH Matthew, "Flamenco for Andalusia, Flamenco for Humanity: Regionalisation and Intangible Cultural Heritage in Spain", ROss Sarah, SWEERs Britta (eds.), Cultural Mapping and Musical Diversity, Sheffield, Equinox Studies in Ethnomusicology, forthcoming.

8. CRUCES RÓLDAN Cristina, El Flamenco como Patrimonio: Anotaciones a la Declaración de los Registros Sonoros de la Niña de los Peines como Bien de Interés Cultural, Sevilla, Ayuntamiento de Sevilla, 2001; 
CRUCES RóLDAN Cristina (ed.), Historia del Flamenco, Sevilla, Ediciones Tartessos, 2002; CRUCES RóLDAN Cristina, Antropología y Flamenco (II), Sevilla, Signatura Ediciones, 2003.

9. See, among many others, CHILD Francis J. (ed.), English and Scottish Ballads, London, Sampson Low, 1861; VASCONCELlos Jorge Leite, Etnografia Portuguesa, Lisboa, INCM, 1994 [1933]; LOMAX Alan, Folk Song Style and Culture, Washington, American Association for the Advancement of Science, 1968.

10. On the use of "authenticity" in the musical realm, see BIGENHO Michelle, Sounding Indigenous: Authenticity in Bolivian Music Performance, New York, Palgrave Macmillan, 2002; FÉLIX Pedro, "Ai se Ele Cai": Uma Etnografia da Prática do Grupo Xutos \& Pontapés [PhD thesis], Lisboa, Departamento de Antropologia, FCSH, Universidade Nova de Lisboa, 2013; WEISENTHAUNET Hans, LINDBERG Ulf, "Authenticity Revisited: The Rock Critic and the Changing Real", Popular Music and Society, vol. 33, no. 4, 2010, p. 465-485. On "revival", see FEINTUCH Burt, "Revivals on the Edge: Northumberland and Cape Breton - a Keynote", Yearbook for Traditional Music, vol. 38, 2006, p. 1-17; LIVINGSTON Tamara E., "Music Revivals: Towards a General Theory", Ethnomusicology, vol. 43, no. 1, 1999, p. 66-85; RONSTRÖM Owe, "Revival Reconsidered”, The World of Music, vol. 38, no. 3, 1996, p. 5-20; scully Michael F., The Never-Ending Revival: Rouder Records and the Folk Alliance, Urbana, University of Illinois Press, 2008.

11. BRIGGS Charles L., "The Politics of Discursive Authority in Research on the "Invention of Tradition"', Cultural Anthropology, vol. 11, no. 4, 1996, p. 435-469 (quote p. 460).

12. FILENE Benjamin, Romancing the Folk: Public Memory and American Roots Music, Chapel Hill, University of North Carolina Press, 2000.

13. HOBSBAWM Eric, "Introduction: Inventing Traditions", HOBSBAWM Eric, RANGER Terence (eds.), The Invention of Tradition, Cambridge, Cambridge University Press, 1983, p. 1-14; ANDERSON Benedict, Imagined Communities. Reflections on the Origin and Spread of Nationalism, London, Verso, 1983; HANDLER Richard, Nationalism and the Politics of Culture in Quebec, Madison, The University of Wisconsin Press, 1988; BoHLman Philip V., The Study of Folk Music in the Modern World, Bloomington, Indiana University Press, 1988; BoISSEVAIN Jeremy (ed.), Revitalizing European Rituals, London / New York, Routledge, 1993; BAUMANN Max Peter, "Folk Music Revival: Concepts Between Regression and Emancipation", The World of Music, vol. 38, no. 3, 1996, p. 71-86; KIRSHENBLATT-GIMBLETT, Destination Culture: Tourism, Museums, and Heritage.

14. UNESCO, "Convention for the Safeguarding of the Intangible Cultural Heritage". ich.unesco.org/ en/convention (accessed August 16, 2019).

15. Ibid.

16. See тsснмиск Peter, Creativity and Innovation in the Music Industry, Heidelberg, Springer, 2012.

17. At arquivosonoro.museudofado.pt (accessed April 16, 2019).

18. See fÉLIX Pedro, Inventário do Património Fonográfico Português: Fado, Lisboa, Museu do Fado, forthcoming; CRUCES RÓLDAN Cristina, El Flamenco como Patrimonio: Anotaciones a la Declaración de los Registros Sonoros de la Niña de los Peines como Bien de Interés Cultural, 2001

19. BITHELL Caroline, HILL Junipper (eds.), The Oxford Handbook of Music Revival, Oxford / New York, Oxford University Press, 2014.

20. TAYLOR Timothy D., Global Pop: World Music, World Markets, London, Routledge, 1997; TAYLOR Timothy D., Beyond Exoticism: Western Music and the World, Durham, Duke University Press, 2007.

21. SHELEMAY Kay Kaufman, "Recording Technology, the Record Industry, and Ethnomusicological Scholarship", NETTL Bruno, BOHLMAn Philip V. (eds.), Comparative Musicology and Anthropology of Music: Essays on the History of Ethnomusicology, Chicago, The University of Chicago Press, 1991, p. 277-292; ROSENBERG Neil (ed.), Transforming Traditions: Folk Music Revivals Examined, Urbana, University of Illinois Press, 1993; BRADY Erica, A Spiral Way: How the Phonograph Changed Ethnography, Jackson, University Press of Mississippi, 1999; EARLMAn Veit, Music, Modernity, and the 
Global Imagination: South Africa and the West, New York, Oxford University Press, 1999; BRASSEAUX Ryan A., Cajun Breakdown: The Emergence of an American-made Music, Oxford, Oxford University Press, 2009; BAYLEY Amanda (ed.), Recorded Music: Performance, Culture and Technology, Cambridge, Cambridge University Press, 2010; MANUEL Peter, "Music Cultures of Mechanical Reproduction", BOHLMan Philip V. (ed.) The Cambridge History of World Music, Cambridge, Cambridge University Press, 2013, p. 55-74.

22. CLARKE Eric, COOK Nicholas (eds.), Empirical Musicology: Aims, Methods, Prospects, Oxford, Oxford University Press, 2004; COOK Nicholas, CLARKE Eric, et al. (eds.), The Cambridge Companion to Recorded Music, Cambridge, Cambridge University Press, 2009; соoK Nicholas, Beyond the Score. Music as Performance, Oxford, Oxford University Press, 2013; cooK Nicholas, PETTENGILl Richard (eds.), Music as Performance: New Perspectives Across the Disciplines, Ann Arbor, University of Illinois Press, forthcoming.

23. JANES Robert R., Museums and the Paradox of Change: A Case Study in Urgent Adaptation, London, Routledge, 2013 [1995]; MARSTINE Janet, Critical Practice. Artists, Museums Ethics, London, Routledge, 2017; SILVERMAn Raymond, Museums as Process. Translating Local and Global Knowledges, London, Routledge, 2014; MACDONALD Sharon, Memorylands. Heritage and Identity in Europe Today, London, Routledge, 2013; MACLEOD Suzanne, HANKS Laura H., HALE Jonathan (eds.), Museum Making. Narratives, Architectures, Exhibitions, London, Routledge, 2012.

24. Some of the most interesting expediencies on exhibition are documented by LATOUR Bruno, HERMANT Emilie, Paris Ville Invisible, Paris, Les Empêcheurs de penser en rond \& Le Seuil, 2009 [1998]; LATOUR Bruno, WEIBEL Peter (eds.), Iconoclash. Beyond the Image Wars in Science, Religion and Art, Cambridge, MIT Press, 2002; LATOUR Bruno, weIBEL Peter (eds.), Making Things Public. Atmospheres of Democracy, Cambridge, MIT Press, 2005; WEIBEL Peter, LATOUR Bruno, "Experimenting with Representation: Iconoclash and Making Things Public", MACDONALD Sharon, BASU Paul (eds.), Exhibition Experiments, Malden, Blackwell Publishing ltd., 2007, p. 94-108; Gagliardi Pasquale, Latour Bruno, MEMelSDorff Pedro (eds.), Coping with the Past. Creative Perspectives on Conservation and Restoration, Firenze, Leo S. Olschki, 2010.

25. See HARRISON Rodney, BYRNE Sarah, CLARKE Anne (eds.), Reassembling the Collection: Ethnographic Museums and Indigenous Agency, Santa Fé, School for Advanced Research Press, 2013.

26. See cotTrell Stephen, "The Rise and Rise of Phonomusicology", BAYley Amanda (ed.), Recorded Music. Performance, Culture and Technology, Cambridge, Cambridge University Press, 2010, p. 15-36.

27. On the role of musicology as an actor in the institutionalization process of "traditional" practices, see HILL Juniper, "The Influence of Conservatory Folk Music Programs: the Sibelius Academy in Comparative Context", Ethnomusicology Forum, vol. 18, ํㅡ 2, 2009, p. 205-239; KEEGANPHIPPS Simon, "Déjà vu? Folk Music, Education, and Institutionalization in Contemporary England", Yearbook for Traditional Music, vol. 39, 2007, p. 84-107.

28. LATouR Bruno, Cogitamus :six lettres sur les humanités scientifiques, Paris, La Découverte, 2010.

29. LATour Bruno, "When Things Strike Back: a Possible Contribution of 'Science Studies' to the Social Sciences", British Journal of Sociology, vol. 51, no. 1, 2000, p. 116.

30. viVEIros DE CASTRo Eduardo, "Cosmological Deixis and Amerindian Perspectivism", The Journal of the Royal Anthropological Institute, vol. 4, no. 3, 1998, p. 469-488.

31. In particular, on popular song during the First World War, automatic music machines (from 1850 to 1927), and perceptions, uses and re-uses of the "traditional" repertoire. This research was (and continues to be) published in various papers, chapters, monographs and conference papers. 32. Currently, with the rising of music associated industries (live and recorded music), this practice tends to be limited to informal and amateur contexts, even if performed there by professional artists. Artists such as Carminho, who has her own group, can easily perform without rehearsal with any musician by simply asking for a traditional tune. Fado performers (whether instrumentalists or singers) know at least 80 to 150 melodies. 
33. SMALL Christopher, Musicking: the Meanings of Performing and Listening, Middletown, Wesleyan University Press, 1998.

34. GEISMAR Haidy, Museum Objects. Lessons for the Digital Age, London, UCL Press, 2018, p. 76.

35. CHRISTIE Michael, vERRAN Helen, "Postcolonial Databasing? Subverting old Appropriations, Developing New Associations", LEACH James, WILSON Lee (eds.), Subversion, Conversion, Development: Cross-Cultural Knowledge Exchange and the Politics of Design, Cambridge, MIT Press, 2014, p. 57-78.

36. CANDLIN Fiona, Micromuseology, London, Bloomsbury Academic, 2015.

37. GEISMAR, Museum Objects. Lessons for the Digital Age, p. 20.

38. See LATour Bruno, Nous n'avons jamais été modernes : essai d'anthropologie symétrique, Paris, La Découverte, 1997.

39. CAMERON Fiona, "Object-Oriented Democracies: Conceptualising Museum Collections in Networks", Museum Management and Curatorship, vol. 23, no. 3, 2008, p. 229-243.

40. In the sense Law uses the expression "messy"; LAW John, After Method: Mess in Social Science Research, London, Routledge, 2004.

41. On indigenous curation and the decolonization of heritage discourse, see LONETREE Amy, Decolonizing Museums: Representing Native America in National and Tribal Museums, Chapel Hill, UNC Press Books, 2012; MITHLo Nancy Marie, “Red Man's Burden: The Politics of Inclusion in Museum Settings”, American Indian Quarterly, vol. 28, no. 3-4, 2004, p. 743-763; RICKARD Jolene, “Absorbing or Obscuring the Absence of a Critical Space in the Americas for Indigeneity: The Smithsonian's National Museum of the American Indian", Res: Anthropology and Aesthetics, no. 52, 2007, p. 85-92.

42. We can identify one root of this process in the social sciences "poetic and politics" movement. See CLIFFORD James, MARCuS George E. (eds.), Writing Culture. The Poetics and Politics of Ethnography, Berkley, University of California Press, 1986.

43. For a detailed account on "assemblage" and its impact on curatorship, see HARRISON Rodney, et al. (eds.), Reassembling the Collection: Ethnographic Museums and Indigenous Agency.

44. PRATT Marie Louise, "Arts of the Contact Zone", Profession, 1991, p. 33-40.

45. The artificiality of the separation between tangible and intangible heritage has been discussed by CIARCIA Gaetano, La perte durable : étude sur la notion de "patrimoine immatériel", Paris, LAHIC / Mission à l'ethnologie, 2006, among so many others, and also reflected in the legal text of the UNESCO Convention.

\section{ABSTRACTS}

HeritaMus is a digital tool for gathering, retrieving and visualizing complex data on heritage (tangible and intangible), thereby promoting participatory curatorship by mobilizing communities of practice. Developed over a three-year period by a European consortium, the project was based on a cooperative ethnography study on the uses and re-uses of historical sound recordings of two cultural manifestations inscribed on the UNESCO ICH list: fado and flamenco. Taking historical sound recordings as a fundamental actor that informs current musical practice, the project focused on overcoming the artificial divide between tangible heritage (historical phonograms) and intangible heritage (musical practice and community of practice knowledge). HeritaMus was designed to display the networks established by all kinds of actors (human and non-human), deepening the understanding of their intricate relationships. 
This paper introduces the theoretical background of the HeritaMus project and the conceptual challenges that the consortium faced while developing the tool, describes the tool's main characteristics and processes, and projects future developments. Some research results are also presented concerning politics of representation, the uneven representation of communities of practice and communities of research, the impact of "heritage excess" and the erasure of controversy among heritage practices-topics that are known to practitioners but often overlooked by academia.

HeritaMus est un outil numérique permettant de rassembler, de récupérer et de visualiser des données complexes portant sur le patrimoine (matériel et immatériel). Il favorise ainsi une curation participative, en mobilisant les communautés de pratique. Développé pendant trois ans par un consortium européen, ce projet repose sur une étude ethnographique coopérative des utilisations et réutilisations d'enregistrements sonores historiques afférents à deux pratiques culturelles inscrites sur la liste du PCI de l'UNESCO : le fado et le flamenco. Considérant ces enregistrements historiques comme des acteurs fondamentaux qui informent les pratiques musicales actuelles, le projet a tenté de surmonter la distinction artificielle entre patrimoine matériel (phonogrammes historiques) et immatériel (pratiques musicales et savoirs des communautés de pratique). HeritaMus a été conçu pour donner à voir les réseaux établis entre toutes sortes d'acteurs (humains et non-humains), afin d'approfondir l'intelligibilité de leurs relations complexes.

Cet article présente le cadre théorique du projet HeritaMus et les défis conceptuels auxquels a été confronté le consortium lors du développement de l'outil. Il décrit également les principales caractéristiques et modes opératoires de cet outil, et envisage les développements futurs du projet. Certains résultats de recherche sont également présentés à propos des enjeux politiques des dispositifs de présentation, de la représentation dissymétriques des communautés de pratique et des communautés de recherche, de l'impact de «l'excès patrimonial», et de l'effacement des controverses au sein des pratiques patrimoniales - des questions bien connues des praticiens mais souvent négligées par le monde universitaire.

\section{INDEX}

Mots-clés: patrimoine, fado, participation des communautés, théorie de l'acteur-réseau, études critiques du patrimoine, curation participative

Keywords: heritage, fado, community participation, actor-network theory, critical heritage, participatory curatorship

\section{AUTHOR}

\section{PEDRO FÉLIX}

Pedro Félix has been a researcher at Instituto de Etnomusicologia since 1997 and at Instituto de História Contemporânea since 2013, and has collaborated with the Museu do Fado since 2005. He has developed fieldwork on musical groups in Portugal, technology, the phonographic publishing industry and sound heritage. He was a member of the research team tasked with preparing the proposal to inscribe fado on the UNESCO ICH list. He has curated exhibitions for the Museu do Fado, currently coordinates the digitization program of the music collection of the Museu do Fado, and co-produced a multi-part relational database for phonograms (among other databases). He is writing on phonographic digitizing processes and know-how acquired through this project and has published several music CDs of historical sound recordings that he digitized and 
restored. Recently, he was co-coordinator of the European HeritaMus project (JPI-CH / ERA-Net programs) (http://heritamus.fcsh.unl.pt/). 